\title{
Analysis of Project Management Practices in Public Sector in Al-Salt Greater Municipality
}

\author{
Amal Fares AL-kharabsheh
}

\begin{abstract}
The study aim at assessing the different project management practices in public sector in al salt greater municipality. To accomplish the target of objective of this study ;the study started with a systematic review of the literature was carried out from textbooks institutional and legal publications periodicals trade and academic journals and articles for seminars and conferences about project management and was followed by perpetrating and conducting a direct survey with a questionnaire distribute survey a questionnaire distributed to General Directors, Directors, Head of Divisions, and Project engineers of related departments in the salt greater municipality. Collected Data was analyzed using descriptive statistical techniques. Computer software Statistical Package for Social Science (SPSS V.22) Based upon the analysis of responses the results of the study showed that there is an efficiency of project management practices followed within al-salt greater municipality and these practices could be consider as high level with reference to best practices.
\end{abstract}

Keywords: Al-Salt Greater Municipality, Project Management, Public.

\section{INTRODUCTION}

Generally speaking, Municipalities have the overall responsibility of services provision and development within their areas; Municipalities are main impression in the control of foremost risks. They have in-depth data of the reality within their territory; their function connect degree interface with the inhabitants and show a actual job in development and in the regulation of activities. They are responsible for local planning and development, and take an dynamic part in crisis management before, during, and after major events [1]. In Jordan, municipalities are public sector which primarily liable for the joining and urban planning and supply public services to citizens. Al-Salt Municipality is one of the most important institutions that implements different infrastructure projects which is important to achieve sustainable development for the city. Al-Salt municipality, the formal governmental implement agency of public sector projects, is measured as a main support and accountable of implementation of government programs in a salt city. And carry out the development and improvement of the infrastructure projects and a construction of buildings which is expected to increase the prosperity of the people and make the quality of the local environment better. The development of infrastructure projects should implement fast, reliable, efficient and effectual, useful and have high capability for

Revised Manuscript Received on December 05, 2020.

* Correspondence Author

Amal Fares AL-kharabsheh*, Civil engineer, Al-Salt grater municipality, Al-Salt, Jordan. Email: ce.amalfares510@yahoo.com

(C) The Authors. Published by Blue Eyes Intelligence Engineering and Sciences Publication (BEIESP). This is an open access article under the CC BY-NC-ND license (http://creativecommons.org/licenses/by-nc-nd/4.0/) competition. So it should fulfill the feasibility of technical, economical, financial, social and environmental, to support the development of economic network locally, nationally, and globally in sustainable manner. To fulfill the demand, project management development should be an important issue in the public sectors. The development of project management practices in al salt municipality is the most important field, since it identifies the methodologies and actions needed to achieve government strategic goals.

The objectives of the research paper are: To evaluate a project management practices and tools apply by the various departments, in $\mathrm{Al}$-Salt Greater municipality. To provide recommendations based on the results of this study to enhance project management practices in al-salt municipality in addition to improve quality of their work and avoid problems

The main aim of this study is to measure a reality of project management practices in al salt greater municipality public sector, also to find effective techniques and tools in project management in Al-Salt Greater municipality within public sector.

Research Hypothesis: H1. There is a deficiency in applied of project management practices in the Public Sector in al salt greater municipality with the best practices.

\section{LITERATURE REVIEE}

The primary point of this part is to supply a required background and information to overcome the research subject and objectives.

\section{A. Project Management Importance}

Project management is calculated to control the significant key basics that supply practical information to reach project goals in efficient manner. Walker knew project management as "The use of resources in the company on a certain activity within time, cost and performance. A fourth key factor is good customer relations" [2].

\section{B. Project Management Definition}

Kerzner outline project management as planning to organize direct and control company resources for short term goal for a relatively long period that is set to achieve precise aims and objectives In addition to that project management uses a systems management approach with functional employees with a vertical hierarchy of a specific project hierarchy horizontal [3].

\section{Project Life Cycle}

All The project life cycle model describes the different stages that the project regularly go through from the beginning to the end.

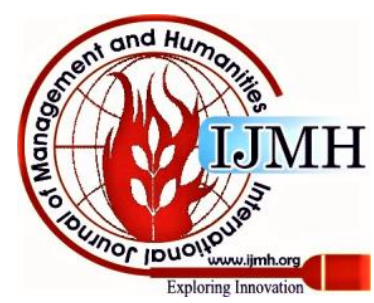




\section{Analysis of Project Management Practices in Public Sector in Al-Salt Greater Municipality}

The project cycle had a structure to ensure the consulting to interested parties made all related information existing throughout the life of the project so that key decisions can be made stages in the life of a project [4]. Based on Westland the project life cycle consist of four phases. Initiation phase, Planning phase, Executing phase and Closing phase.

The initiation phase of the project is the conceptualization of the project the main aim of the project initiation phase is to indicate what the project must comply. caution in this purpose lies in client needs if goals are poorly uttered and defectively formulated and the objectives shall be highlighted as a major source of concern.

Planning Phase is subsequent to documentation of the costs and benefits of the project, and identification of the objectives and scope also the project team has been selected and a formal project office environment set up at this point it's a time to assume comprehensive planning to make certain that the carried activities through the execution phase of the project are accurately sequenced accomplish with resources executed and controlled [3].

The execution phase is typically the longest stage of the project in conditions of duration .It is the part within which the deliverables are physically build and presented to the customer for agreement to guarantee that customer needs are met the project manager supervises and controls the activities resources and expenses necessary to build each deliverable various management processes which carried out to ensure that the project progresses as planned This phase include the implementation of the plans done during the project planning stage [5]. Upon acceptance of all project deliverables the project covers the goals and ready to close the closing of the project implies delivering the final deliverables to the stakeholder's delivery of project documentation supplier completion contracts and release of project resources. [4].

\section{METHODOLOGY}

So as to clarify main idea about project management practices in al- salt greater municipality in addition test identified hypotheses .two step of study was carried out:

- Literature Review, initially with an outline of the topics interested in this research.

-Data collection by prepare a questionnaire and conduct survey with a questionnaire.

\section{A. Questionnaire}

A questionnaire was considered as the primary tool to comply with the investigation purposes and to test hypotheses. Based on information illustrated in the previous chapter which help the researcher's to widen knowledge and raise realization of other issues that would not have then be raised Keeping in mind. Second the experience of the researcher in the project public sector management also helped formulate the questionnaire.

a developed questionnaire was cover all the aspects to accomplish the aim of the research. To ensure reliability of questionnaire a quality control process was carried .each objective and hypothesis had questions corresponding to going through a practical test in which specialists were asked to the questionnaire to examine the level of clarity.

The questionnaire divided into three sections: section one contained a personal data about the study sample age, qualification, position and years of experience. section two contained of thirty three elements to assess the reality of the project management cycle.

likert scale with four points scale was used and the scores of the participants to each item was calculate based on 4 point for totally agree 3 points agree 2 points disagree 2 and 1 point for strongly disagree..

. Four Points were taking into account to achieve a high-level of response :

- Provide a cover letter.

- Intelligent and attractive design.

- Multiple choice formats.

- Maintain a short questionnaire so that it can be completed in 10 - 15minutes.

Since the mother tongue of most people working in the public sector is Arabic it was needed to make available of a questionnaire in Arabic format. For quick interaction the questionnaire was spread and hand-picked.

\section{B. Survey Sample}

The sample members of this research consist of 21 decision makers working in related departments al-Salt greater municipality which classified according to four categories: age , job titles , years of experience and Qualification.

\section{Method of analysis}

A descriptive statistical techniques was chosen to analysis collected Data from the survey. computer software Statistical Package for Social Science (SPSS V.22) was selected as the best options available to arrange the data in a fast, reliable and systematic way.

\section{DATA ANALYSIS AND DICUSSION}

Table- I show that $85.7 \%$ of practitioners have a bachelor degree while $14.3 \%$ have a master's degree.

Table- I: sample Distribution based on Qualification Education

\begin{tabular}{|c|r|r|r|r|}
\hline & $\begin{array}{c}\text { Frequenc } \\
\text { y }\end{array}$ & Percent & \multicolumn{1}{|c|}{$\begin{array}{c}\text { Valid } \\
\text { Percent }\end{array}$} & $\begin{array}{c}\text { Cumulative } \\
\text { Percent }\end{array}$ \\
\hline BA & 18 & 85.7 & 85.7 & 85.7 \\
Master & 3 & 14.3 & 14.3 & 100.0 \\
Total & 21 & 100.0 & 100.0 & \\
\hline
\end{tabular}

Table-II below shows that $38.1 \%$ have a 5-10 year experience while $33.3 \%$ have an $11-15$ year experience and $28.6 \%$ have more than 15 year experience.

Table- II: sample Distribution based on Qualification

\begin{tabular}{|l|r|r|r|r|}
\hline & & & & Cumulative \\
& Frequency & Percent & Valid Percent & Percent \\
\hline $5-10 \mathrm{yr}$ & 8 & 38.1 & 38.1 & 38.1 \\
$11-15 \mathrm{yr}$ & 7 & 33.3 & 33.3 & 71.4 \\
more than 15 yr & 6 & 28.6 & 28.6 & 100.0 \\
Total & 21 & 100.0 & 100.0 & \\
\hline
\end{tabular}

Published By:

Blue Eyes Intelligence Engineering \& Sciences Publication

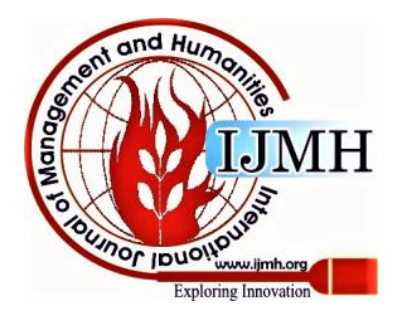


Table-III below shows that $33.3 \%$ have a $25-35$ year age while $28.6 \%$ have an $36-45$ year age and $38.1 \%$ have more than 45 year age.

Table- III: sample Distribution based on Age

\begin{tabular}{|l|r|r|r|r|}
\hline & Frequency & Percent & Valid Percent & $\begin{array}{c}\text { Cumulative } \\
\text { Percent }\end{array}$ \\
\hline 25.35 year & 7 & 33.3 & 33.3 & 33.3 \\
36.45 year & 6 & 28.6 & 28.6 & 61.9 \\
more 45 year & 8 & 38.1 & 38.1 & 100.0 \\
Total & 21 & 100.0 & 100.0 & \\
\hline
\end{tabular}

Table-IV below shows that $4.8 \%$ are general director while $23.8 \%$ are director and $14.3 \%$ are head of division and others are $57 \%$.

Table- IV: Sample Distribution Based on Job Title

\begin{tabular}{|l|r|r|r|r|}
\hline & & & & Job Title \\
& Frequency & Percent & Valid Percent & \multicolumn{1}{c|}{\begin{tabular}{c} 
Percent \\
\hline Valid General Director
\end{tabular}} \\
& 1 & 4.8 & 4.8 & 4.8 \\
director & 5 & 23.8 & 23.8 & 28.6 \\
head of division & 3 & 14.3 & 14.3 & 42.9 \\
other/engineer & 12 & 57.1 & 57.1 & 100.0 \\
Total & 21 & 100.0 & 100.0 & \\
\hline
\end{tabular}

The researcher computes the means, standard deviations, and levels, for items of reality of project cycle management to answer the questions of the research.

Table- V: Project Identification phase which total score have a mean of (3.4762) and a standard deviation of (0.51177) and show a highly level of assessment. That means the projects were highly developed in line of the state or municipality strategic plans.

Table- V: Descriptive Statistics of Project Formulation Phase

Descriptive Statistics

\begin{tabular}{|l|c|c|c|}
\hline & Mean & Std. Deviation & Level \\
\hline $\begin{array}{l}\text { The project is convenient with the } \\
\text { Municipality Strategy? } \\
\text { The project is convenient with the } \\
\text { State Strategy? }\end{array}$ & 3.5714 & .74642 & High \\
Total score IAverage & 3.3810 & .74001 & High \\
\hline
\end{tabular}

Project formulation phase which total scores have a mean of 3.069 and a standard deviation of 0.19869 which indicates a high level of formulation phase. Where Appoint Project Team from the Beginning And Setting up "Job Description" for project team Have the highest mean which is equal to 3.333 which is high level of assessment and Studying sustainability for the project has the lowest mean equal to 2.5714 which is moderated level of assessment. as illustrate in table - VI.
Table- VI: Descriptive Statistics of Project Formulation Phase Based On Analysis

\begin{tabular}{|c|c|c|c|}
\hline \multicolumn{4}{|c|}{ Descriptive Statistics } \\
\hline & Mean & $\begin{array}{c}\text { Std. } \\
\text { Deviation } \\
\end{array}$ & Level \\
\hline $\begin{array}{l}\text { Undertaking Feasibility Study } \\
\text { for the project? }\end{array}$ & 3.2381 & .76842 & high \\
\hline $\begin{array}{l}\text { Studying environmental impact } \\
\text { assessment? }\end{array}$ & 2.9524 & .74001 & Moderate \\
\hline $\begin{array}{l}\text { Studying sustainability for the } \\
\text { project? }\end{array}$ & 2.5714 & .87014 & Moderate \\
\hline Studying risks of the project? & 2.6667 & .65828 & Moderate \\
\hline $\begin{array}{l}\text { Studying Operation and } \\
\text { Maintenance of the project on } \\
\text { short and long term? }\end{array}$ & 3.2381 & .53896 & High \\
\hline $\begin{array}{l}\text { Appoint Project Team from the } \\
\text { Beginning? }\end{array}$ & 3.3333 & .48305 & High \\
\hline Set up Project Office? & 3.2381 & .70034 & High \\
\hline $\begin{array}{l}\text { Studying all project } \\
\text { requirements? }\end{array}$ & 3.2857 & .56061 & High \\
\hline $\begin{array}{l}\text { Preparing "Project Charter" } \\
\text { which describes scope, } \\
\text { objectives, time, budget, and } \\
\text { risks? }\end{array}$ & 2.7619 & .62488 & Moderate \\
\hline $\begin{array}{l}\text { Setting up "Job Description" } \\
\text { for project team? }\end{array}$ & 3.3333 & .48305 & High \\
\hline Total score Average & 3.0619 & 19869 & High \\
\hline
\end{tabular}

planning phase which total score have a mean of (3.1964) and a standard deviation of 0.28110 as shown in table-VII which signify as a high level of application of planning phase Which is consider as a critical phase of the project cycle management it is important to avoid budget deficits and late deliveries. Based on the results mentioned below mean that the municipality get attention to this phase.

Table- VII: Descriptive Statistics Of The Items Of The Planning Phase

\begin{tabular}{|l|c|c|c|}
\hline \multicolumn{1}{|c|}{ Descriptive Statistics } & Mean & Std. Deviation & Level \\
\hline $\begin{array}{l}\text { Preparing detailed plan describes } \\
\text { how to implement the project? } \\
\text { Preparing financial detailed plan } \\
\text { shows the costs required during the } \\
\text { implementation phases of the }\end{array}$ & 3.1429 & .79282 & High \\
project? & 3.1905 & .74960 & High \\
$\begin{array}{l}\text { Determining quality target? } \\
\text { Developing quality plan to monitor the } \\
\text { quality of the outputs and to identify } \\
\text { actions that will be used to achieve } \\
\text { the required quality? }\end{array}$ & 3.6190 & .49761 & High \\
$\begin{array}{l}\text { Preparing procurement plan? } \\
\text { Preparing clear term of references for } \\
\text { tendering documents? }\end{array}$ & 3.9524 & .66904 & Moderate \\
Preparing risk plan for the project? & 2.9048 & .53896 & Migh \\
$\begin{array}{l}\text { Preparing communication plan for all } \\
\text { related parties? }\end{array}$ & 3.3333 & .79582 & High \\
Total score IAverage & 3.1964 & .28110 & High \\
\hline
\end{tabular}

Table- VIII show that execution phase which total score have a mean of (3.1810) and standard deviation of 0.26948 which signify as a high level of execution phase. Where managing risks effectively has the lowest mean equal to 2.5714 which is moderated level of application.

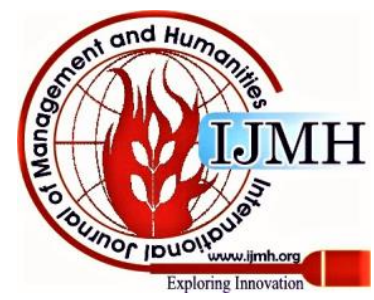


Table- VIII: Descriptive Statistics of the Items of The Execution Phase

\begin{tabular}{|l|c|c|c|}
\hline \multicolumn{1}{|c|}{ Descriptive Statistics } & Mean & Std. Deviation & Level \\
\hline $\begin{array}{l}\text { Controlling and management } \\
\text { activities carried out by the project } \\
\text { team? }\end{array}$ & 3.3333 & .65828 & High \\
$\begin{array}{l}\text { Managing costs so it does not } \\
\text { exceed the allocated budget for the } \\
\text { project? }\end{array}$ & 3.5714 & .59761 & High \\
$\begin{array}{l}\text { Managing time effectively? } \\
\text { Managing bidding processes } \\
\text { effectively? }\end{array}$ & 3.1429 & .57321 & High \\
$\begin{array}{l}\text { Using mechanisms to monitor quality } \\
\text { during the implementation of } \\
\text { effective (quality assurance)? } \\
\text { Setting standards for the delivery of } \\
\text { project outputs? }\end{array}$ & 3.0000 & .54772 & High \\
$\begin{array}{l}\text { Managing risks effectively? } \\
\text { Managing changes that arise during } \\
\text { the implementation of the project } \\
\text { effectively and properly? }\end{array}$ & 3.1905 & .60159 & High \\
$\begin{array}{l}\text { Managing communication among all } \\
\text { relevant parties effectively? }\end{array}$ & 3.1429 & .51177 & High \\
$\begin{array}{l}\text { Managing problems and issues that } \\
\text { arise during the implementation of } \\
\text { the projecteffectively? } \\
\text { Total score lAverage }\end{array}$ & 3.1429 & .66291 & Moderate \\
\hline
\end{tabular}

project closure phase which total score have a mean of (3.1429) and standard deviation of 0.34272 which signify as a high level of application of it as illustrate in table-IX below.

Table- IX: Descriptive Statistics of the Items of the Project Closure

\begin{tabular}{|l|c|c|c|}
\hline \multicolumn{1}{|c|}{ Descriptive Statistics } & \multicolumn{1}{c|}{$\begin{array}{c}\text { Std. } \\
\text { Deviation }\end{array}$} & Level \\
\hline $\begin{array}{l}\text { Evaluating the project } \\
\text { after the voting to } \\
\text { determine the level of } \\
\text { achievement of the } \\
\text { objectives of the project } \\
\text { and its success and } \\
\text { lessons learned? } \\
\begin{array}{l}\text { Disseminating the lessons } \\
\text { learned from the project? }\end{array}\end{array}$ & 2.6190 & .58959 & Moderate \\
$\begin{array}{l}\text { Documenting and archive } \\
\text { all Documentation for the } \\
\text { project after finishing? }\end{array}$ & 3.4762 & .51177 & High \\
\begin{tabular}{l} 
Total score lAverage \\
\hline
\end{tabular} & 3.1429 & .34272 & High \\
\hline
\end{tabular}

Table- X showed the results of the reality of Project Cycle Management and illustrated the total score of the reality of Project Cycle Management which reach a mean of 3.2117and a standard division 0.17211 that indicates a high level of reality of project cycle management.

\section{Table-X: Descriptive Statistics of the Project Cycle Management Domains}

\begin{tabular}{|c|c|c|c|}
\hline \multicolumn{4}{|c|}{ Descriptive Statistics } \\
\hline & Mean & $\begin{array}{c}\text { Std. } \\
\text { Deviation }\end{array}$ & Level \\
\hline Project closure & 3.4762 & .51177 & High \\
\hline $\begin{array}{l}\text { After Project } \\
\text { Identification }\end{array}$ & 3.0619 & 19869 & High \\
\hline Planning phase & 3.1964 & .28110 & High \\
\hline Project Identification & 3.1810 & .26948 & High \\
\hline Execution phase & 3.1429 & .34272 & High \\
\hline $\begin{array}{l}\text { Total score } \\
\text { laverage }\end{array}$ & 3.2117 & .17211 & high \\
\hline
\end{tabular}

Results Associated with the research Hypothesis show that There are no significant differences at $(=0.05)$ between the degree of analysis of Project Management Practices in al-salt greater municipality and the criteria which the researcher used One Sample T-Test. Table- XI shows the results.

Table- XI: One Sample T-Test to Test the Research Hypothesis

\begin{tabular}{|c|c|c|c|c|c|c|}
\hline \multicolumn{7}{|c|}{ One-Sample Test } \\
\hline & \multicolumn{6}{|c|}{ Test Value $=0$} \\
\hline & \multirow[b]{2}{*}{$T$} & \multirow[b]{2}{*}{ Df } & \multirow[b]{2}{*}{ Sig. (2-tailed) } & \multirow{2}{*}{$\begin{array}{c}\text { Mean } \\
\text { Difference }\end{array}$} & \multicolumn{2}{|c|}{$\begin{array}{c}95 \% \text { Confidence Interval } \\
\text { of the Difference }\end{array}$} \\
\hline & & & & & Lower & Upper \\
\hline Project closure & 31.127 & 20 & .000 & 3.47619 & 3.2432 & 3.7091 \\
\hline After Project & & & & & & \\
\hline Identification & 70.621 & 20 & .000 & 3.06190 & 2.9715 & 3.1523 \\
\hline Planning phase & 52.109 & 20 & .000 & 3.19643 & 3.0685 & 3.3244 \\
\hline Project Identification & 54.093 & 20 & .000 & 3.18095 & 3.0583 & 3.3036 \\
\hline Execution phase & 42.023 & 20 & .000 & 3.14286 & 2.9869 & 3.2989 \\
\hline
\end{tabular}

\section{RECOMMENDATIONS}

A research show that al -Salt greater municipality has a high level of application of project management practices in their project in each phase of project life cycle.

- It is recommended to co-relate with further public agency in order to barter experiences in project management areas.

- It would be helpful if a comparative study of project management practices in public sector is carried out with another public agency in this field.

- Additional studies would be useful to study exact techniques and inspect certain tools applied internationally in specific domains of project management.

- A future expansion ought to take account of the private companies who are working on the projects of the municipality, to study and compare the results.

\section{REFERENCES}

1. Rammal., Iyad, and Samah Abuoun Hamad. “ Planning Capacities within the Palestinian Municipalities, Municipal Development and Lending Fund , Palestinian Authority ." world wide web http://scholar.najah.edu/.../planning-capacities-within-palestinianmunic ipaliti, 2008W.-K. Chen, Linear Networks and Systems (Book style). Belmont, CA: Wadsworth, 1993, pp. 123-135.

2. Fitsilis, Panos, and Thomas Chalatsis. "Adoption of Project Management Practices in Public Organizations." Published Online September 2014 in SciRes. http://www.scirp.org/journal/ib, 2014..

3. Kerzner, H. "Project Management A system Approach to Planning Schedualing and Controlling”, ,. Ohio : John Willey \& Sons, 2006.

4. Westland, Jason. "The Project Management Life Cycle”. Kogan Page, 2006.

5. Walker, A. Project Management in Construction. Oxford, Blakcwell, Oxford , Blakcwell, 2007.

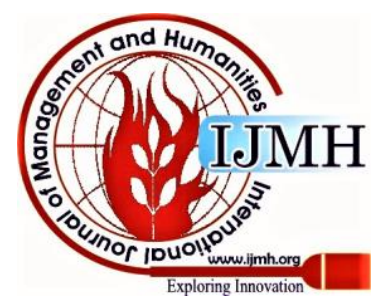




\section{AUTHORS PROFILE}

Amal Fares Al-kharabsheh, master degree in engineering project management, bachelor degree in civil engineering, work as a civil engineer in al-Salt greater municipality.

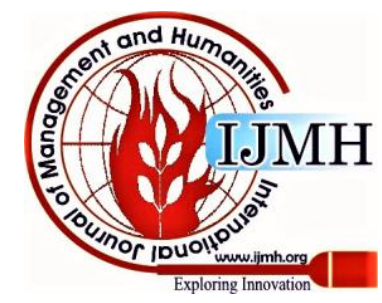

